\title{
PENGARUH PEMBELAJARAN IPS BERBASIS ICT (INFORMATION AND COMMUNICATIONS TECHNOLOGY) DENGAN APLIKASI LECTORA INSPIRE DALAM MENINGKATKAN HASIL BELAJAR SISWA
}

\author{
$\underline{\text { Heri Maria Zulfiati }}$ \\ Pendidikan Guru Sekolah Dasar FKIP UST \\ Email : mariazulfiati@yahoo.com, Hp. 087739544072
}

\begin{abstract}
Abstrak
Pertumbuhan yang cepat dari Teknologi Informasi dan Komunikasi (TIK) dalam pendidikan memungkinkan siswa untuk mengakses bahan belajar yang lengkap dari berbagai sumber. Para siswa didorong untuk belajar mandiri dan mereka menjadi subyek belajar (student centered) dan guru dituntut inovatif. Penelitian ini bertujuan untuk mengetahui Pengaruh Pembelajaran IPS berbasis ICT menggunakan Lectora Inspire dalam meningkatkan hasil belajar dari pada buku-buku teks. Penelitian ini merupakan penelitian eksperimental kuasi dilakukan di SD Negeri Gedongtengen Yogyakarta pada semester 2 tahun ajaran 2012/2013. Desain penelitian yang digunakan adalah Kelompok Kontrol acak desain pretest-posttest. Populasi penelitian adalah seluruh siswa kelas IV SD Negeri Gedongtengen Yogyakarta. Sampel diambil dengan menggunakan teknik ketersediaan sampling. Data dikumpulkan dengan menggunakan tes dan kuesioner. Perbedaan hasil belajar IPS serta minat siswa belajar IPS antara kelas eksperimen dan kontrol dianalisis dengan menggunakan t-test independen untuk mengetahui pengaruh pembelajaran IPS berbasis ICT dengan aplikasi Lectora Inspire. Hasil penelitian ini adalah (1) hasil belajar siswa dengan menggunakan ICT aplikasi Lectora Inspire lebih tinggi daripada menggunakan buku teks $(t=9,226$ dan $p=0,004<a=0,05$, (2) minat belajar siswa menggunakan ICT dengan aplikasi Lectora Inspire lebih tinggi daripada menggunakan buku teks $(\mathrm{t}=7,098$ dan $\mathrm{p}=0,001<\mathrm{a}=0,05)$.
\end{abstract}

Kata kunci : ICT , Hasil Belajar 


\begin{abstract}
Rapid growth of the Information and Communication Technology (ICT) in education enable the students to access complete learning materials from various experts in their fields. The students are encouraged to learn idependently and they become the subjects of the learning (student centered). The teachers should be innovative. This research is aimed to find out the Influence of Social Learning using ICT Lectora Inspire Based is more effective to improve learning results than the text books learning process is. This research was a quasi experimental research conducted at SD Negeri Gedongtengen Yogyakarta in semester 2 the academic year of 2012/2013. The research design used was randomized Control Group Pretestposttest design. The research population was all students of grade IV of SDN Gedongtengen Yogyakarta. The sample was drawn using the availability sampling technique. The data were collected using a test and a questionnaire. The differences of students' learning results of Social Studies as well as students' learning interest between experiment and control groups were examined by using the independent t-test to know the influence of social studies learning using ICT Lectora Inspire Based. Conclusion in this study is (1) the students' learning result using Using ICT Lectora Inspire Based is higher than using textbooks ( $t=9.226$ dan $p=0.004<a=0.05$; (2) the students' learning interest using Using ICT Lectora Inspire Based is higher than using textbooks ( $t=7.098$ dan $p=0.001<a=0.05)$.
\end{abstract}

Keywords: ICT , Learning Results

\title{
Pendahuluan
}

Pendidikan Ilmu Pengetahuan Sosial (IPS) sebagai salah satu bidang studi yang mengarahkan siswa pada upaya mempelajari kehidupan sosial yang bertujuan agar siswa mampu mengembangkan pengetahuan dan ketrampilan dasar yang berguna bagi dirinya dalam menghadapi permasalahan dalam kehidupan sehari-hari, dimana pendidikan IPS ini membekali siswa untuk dapat mengembangkan penalarannya disamping aspek nilai dan moral. Adapun bagi pendidik dan calon pendidik, tujuan IPS diharapkan mampu mempersiapkan, membina dan membentuk kemampuan peserta didik yang menguasai, sikap, 
nilai, dan kompetensi dasar yang diperlukan bagi kehidupan di masyarakat (Etin Solihatin, 2007: 1). Untuk menunjang tercapainya misi dan tujuan tersebut, maka proses pembelajaran harus didukung oleh iklim yang kondusif, antara lain metode pembelajaran yang menyenangkan sehingga kompetensikompetensi tersebut terkuasai.

Pada mata pelajaran IPS siswa diharapkan memiliki kemampuan: "untuk mengembangkan pengetahuan,nilai,sikap dan ketrampilan masyarakat, bangsa dan Negara Indonesia " (Depdiknas, 2003). Pada saat sekarang ini dunia pendidikan sedang menghadapi masa globalisasi yang siap tidak siap harus dapat mengikuti kemajuan yang terus berpacu dalam waktu, jika seorang guru tidak dapat mengikuti perkembangan yang ada maka harus bersiap untuk menghadapi keterbelakangan, ketinggalan dan keterpurukan dalam informasi bidang pendidikan, karena guru merupakan ujung tombak dalam pelaksana pendidikan.

Adel Bahrum (Maria Heri, 2011:1) mengatakan bahwa realitas empirik selama ini di tingkat persekolahan memperlihatkan, dalam proses pembelajaran IPS, guru IPS kurang optimal baik di dalam memanfaatkan maupun memberdayakan sumber pembelajaran, karena dalam proses pembelajaran IPS cenderung masih berpusat pada guru (teacher centered), textbook centered, dan monomedia. Adalah tidak dapat dipersalahkan apabila banyak siswa mengganggap proses pembelajaran IPS sebagai sesuatu yang membosankan, monoton, kurang menyenangkan, terlalu banyak hafalan, kurang variatif, dan pelbagai keluhan lainnya.

Keberhasilan pembelajaran pada ranah kognitif dan psikomotor dipengaruhi oleh kondisi afektif peserta didik. Peserta didik yang memiliki minat belajar dan sikap positif 
terhadap pelajaran akan merasa senang mempelajari mata pelajaran tertentu, sehingga dapat mencapai hasil pembelajaran yang optimal. Hal ini sejalan dengan yang disampaikan Popham (1995) bahwa ranah afektif menentukan keberhasilan belajar seseorang. Orang yang tidak memiliki minat pada pelajaran tertentu sulit untuk mencapai keberhasilan belajar secara optimal. Seseorang yang berminat dalam suatu mata pelajaran diharapkan akan mencapai hasil pembelajaran yang optimal.

Oleh karena itu semua pendidik harus mampu membangkitkan minat semua peserta didik untuk mencapai kompetensi yang telah ditentukan. Selain itu ikatan emosional sering diperlukan untuk membangun semangat kebersamaan, semangat persatuan, semangat nasionalisme, rasa sosial, dan sebagainya. Untuk itu semua dalam merancang program pembelajaran, satuan pendidikan harus memperhatikan ranah afektif. Dengan alasan tersebut di atas yang merupakan fokus dalam penelitian ini adalah hasil belajar ditinjau dari kemampuan kognitif dan afektif dalam hal ini adalah aspek minat belajar siswa tehadap pembelajaran IPS.

Berdasarkan beberapa fakta di atas dan juga data hasil belajar yang belum sesuai dengan nilai KKM (Kriteria Ketuntasan Minimal) 70, mengindikasikan bahwa proses pembelajaran masih diwarnai dengan model teacher centered, mata pelajaran IPS masih disajikan lebih banyak dengan porsi ceramah, media pembelajaran belum bervariasi, siswa sangat kecil keterlibatannya dalam proses pembelajaran. Dengan kata lain siswa tidak dilibatkan secara aktif dalam proses pembelajaran yang sedang berlangsung, meskipun diketahui salah satu alternative untuk 
meningkatkan pembelajaran adalah adanya komunikasi yang interaktif antara guru, peserta didik dan bahan ajar.

Media ajar berbasis ICT dengan aplikasi Lectora Inspire memungkinkan adanya optimalisasi keterlibatan seluruh indra siswa dapat menyajikan sebuah tampilan berupa teks dan multidimensional dengan simpulan secara interaktif. Tampilan tersebut dapat akan membuat pengguna (user) lebih leluasa memilih, dan mengelaborasi pengetahuan yang ingin dipahaminya.

Dengan demikian, pembelajaran dengan menggunakan media berbasis ICT dapat mengakomodasi siswa yang lamban menerima pelajaran, karena komputer bisa menjalankan instruksi yang berulang, seperti yang diiginkan. Iklim afektif ini akan melibatkan penggambaran ulang berbagai obyek yang ada dalam pikiran siswa. Iklim inilah yang membuat tingkat retensi siswa pengguna komputer multimedia lebih tinggi dari pada pengguna, atau dengan kata lain, pembelajaran berbasis ICT dengan aplikasi Lectora Inspire diharapkan mampu menciptakan lingkungan belajar yang menyediakan opsi yang mampu menstimulasi pembelajar untuk menggunakan meningkatkan hasil belajar secara maksimal.

\section{Kemampuan siswa}

Kemampuan (ability) berarti kapasitas seorang individu untuk melakukan beragam tugas dalam suatu pekerjaan. (Stephen P.Robbins \& Timonthy A. Judge, 2009: 57). Menurut Tuminto (2007: 423) menyatakan bahwa kemampuan merupakan kesanggupan, kecakapan, atau kekuatan. Sedangkan menurut Davis dalam Mangkunegara (2000: 67) secara psikologis, kemampuan (ability) terdiri dari kemampuan potensi (IQ) dan kemampuan reality (knowledge skill). 


\section{Kemampuan Kognitif}

Menurut Sudijono (2001: 49) ranah kognitif adalah ranah yang mencakup kegiatan mental (otak). Robert M. Gagne dalam W.S.Winkel (1996: 102) juga menyatakan bahwa "ruang gerak pengaturan kegiatan kognitif adalah aktivitas mentalnya sendiri." Lebih lanjut Gagne menjelaskan bahwa "pengaturan kegiatan kognitif mencakup penggunaan konsep dan kaidah yang telah dimiliki, terutama bila sedang menghadapi suatu problem.

Dari beberapa pendapat di atas dapat disimpulkan bahwa kemampuan kognitif adalah penampilan yang dapat diamati dari aktivitas mental (otak) untuk memperoleh pengetahuan melalui pengalaman sendiri. Pengaturan aktivitas mental dengan menggunakan kaidah dan 12 konsep yang telah dimiliki yang kemudian direpresentasikan melalui tanggapan, gagasan, atau lambang.

\section{Kemampuan Afektif}

Menurut Krathwohl (Maria Heri, 2011: 28) bila ditelusuri hampir semua tujuan kognitif mempunyai komponen afektif. Ada 5 (lima) tipe karakteristik afektif yang penting, yaitu sikap, minat, konsep diri, nilai, dan moral. Dari beberapa tipe karakteristik afektif ini, dalam penelitian ini hanya dibatasi pada karakteristik Sikap dan Minat.

Sikap merupakan suatu kecendrungan untuk bertindak secara suka atau tidak suka terhadap suatu objek. Sikap dapat dibentuk melalui cara mengamati dan menirukan sesuatu yang positif, kemudian melalui penguatan serta menerima informasi verbal. Perubahan sikap dapat diamati dalam proses pembelajaran, tujuan yang ingin dicapai, keteguhan, dan konsistensi terhadap sesuatu. 
Minat sering dihubungkan dengan keinginan atau ketertarikan terhadap sesuatu yang datang dari dalam diri seseorang tanpa ada paksaan dari luar. Minat menurut Slameto (2010:180) adalah "suatu rasa lebih suka dan rasa keterikatan pada satu hal atau aktivtas tanpa ada yang menyuruh". Sedangkan menurut Crow and Crow (dalam Djaali 2006:121) mengatakan bahwa minat berhubungan dengan gaya gerak yang mendorong seseorang untuk menghadapi atau berurusan dengan orang, benda, kegiatan, danpengalaman.

Dari berbagai pendapat yang telah dikemukakan, dapat disimpulkan bahwa minat merupakan rasa suka atau tertarik terhadap suatu hal atau aktivitas seseorang yang mendorongnya untuk melakukan sesuatu kegiatan. Minat sangat besar pengaruhnya terhadap hasil belajar, karena apabila bahan pelajaran yang dipelajari tidak sesuai dengan minat, siswa tidak akan belajar dengan baik sebab tidak menarik baginya.

\section{Kemampuan Psikomotorik}

Keterampilan motorik (motoric skills) berkaitan dengan serangkaian gerak-gerik jasmaniah dalam urutan tertentu dengan mengadakan koordinasi antara gerak-gerik berbagai anggota badan secara terpadu. W.S.Winkel (1996: 339) memaparkan: "Biarpun belajar keterampilan motorik mengutamakan gerakangerakan seluruh otot, urat-urat dan 15 persendian dalam tubuh, namun diperlukan pengamatan melalui alat-alat indera dan pengolahan secara kognitif yang melibatkan pengetahuan dan pemahaman".

\section{Pembelajaran Ilmu Pengetahuan Sosial SD}

Pengertian Ilmu Pengetahuan Sosial yang dalam literature asing dikenal dengan social studies yang dapat diartikan sebagai penelaahan tentang masyarakat. Ilmu Pengetahuan Sosial (Social 
Studies) menurut Mayhood dkk., (1991: 10), adalah "The Social Studies are comprissed of those aspests of history, geography, and philosophy which in practice are selected for instructional purposes in schools and collegs"

Dari beberapa pengertian tentang IPS dapat ditarik suatu konsep yang satu dengan yang lainnya memberikan garis besar yang sama. IPS merupakan perpaduan dari berbagai cabang ilmuilmu sosial, antara lain seperti antropologi, bahasa, ekonomi, filsafat, geografi, hukum, sejarah, sosiologi, politik, dan psikologi sosial. Ilmu pengetahuan sosial dirumuskan atas dasar kenyataan dan gejala sosial yang mewujudkan satu pendekatan terpadu dari aspek dan cabang ilmu-ilmu sosial. Oleh sebab itu, IPS merupakan bagian dari kurikulum sekolah yang diturunkan dari isi materi cabang-cabang ilmu-ilmu sosial di atas.

\section{Media Pembelajaran IPS}

Media Pembelajaran IPS (Ilmu Pengetahuan Sosial) sebagai salah satu komponen pembelajaran, tidak dapat luput dari pembahasan sistem pembelajaran secara menyeluruh. Pemanfaatan media merupakan bagian yang harus mendapat perhatian guru dalam setiap kegiatan pembelajaran. Namun kenyataannya, media pembelajaran pengetahuan sosial masih sering terabaikan dengan berbagai macam alasan, diantaranya terbatasnya waktu untuk membuat persiapan, sulit mencari media yang tepat, tidak adanya dana, dan lain sebagainya. Heinich, et al (1996:8) mengemukakan

"A medium (plural, media) is a channel of communication, derived from the latin word meaning "between" the term refers to anything that carries information between a source and receiver. Examples, include film, television, diagaram, printed material, computer, and instructor. These are considered instructional media when they carry message with a instructional purpose of media is to facilitate communication". 
Maksud dari pernyataan tersebut bahwa media merupakan sarana untuk berkomunikasi, yang berasal dari bahasa latin yang artinya"di antara" yang berarti sesuatu yang membawa informasi di antara sumber dan penerima. Contohnya film, televisi, diagram, materi cetak, computer, dan instruktur. Mereka dipandang sebagai media instruksional yang membawa pesan dengan tujuan instruksional. Dari berbagai batasan di atas maka dapat disimpulkan bahwa media pembelajaran adalah segala wujud yang dapat digunakan sebagai sumber belajar yang dapat merangsang pikiran, perasaan, perhatian, dan kemauan siswa sehingga mendorong terjadinya proses belajar mengajar ketingkat yang lebih efektif dan efisien.

\section{Media Pembelajaran berbasis ICT dengan aplikasi Lectora Inspire sebagai media Pembelajaran IPS}

Menurut Sigit Suryono (http://ciget.info/?p=326) Lectora Inspire merupakan salah satu program aplikasi yang dapat digunakan untuk membuat presentasi maupun media pembelajaran. Keunggulan lectora inspire sangat user friendly "mudah digunakan" dalam pembuatan media pembelajaran.

\section{Media Cetak sebagai Media Pembelajaran IPS}

Media cetak adalah jenis media yang paling banyak digunakan dalam proses belajar. Jenis media ini memliki bentuk yang sangat bervariasi, mulai dari buku, brosur, leaflet, studi guide, jurnal dan majalah ilmiah. Buku adalah media yang bersifat fleksibel (luwes) dan biaya pengadaannya relatif lebih murah jika dibandingkan dengan pengadaan media lain. Penggunaan media cetak dalam proses pembelajaran dapat dikombinasikan dengan jenis media lainnya. Pada umumnya media ini digunakan sebagai informasi utama atau bahkan suplemen informasi terhadap penggunaan media lain (Hujair AH. Sanaky, 2009: 48). 


\section{Metode Penelitian}

Penelitian ini merupakan peneltian kuantitatf dengan menggunakan metode kuasi eksperimen (quasi xpermental design) Metode ini digunakan untuk menguji coba suatu metode pembelajaran dengan sengaja membangkitkan timbulnya sesuatu kejadian, kemudian diteliti bagaimana akibatnya. Adapun rancangan penelitian menggunakan Pretest-posttest Control Group Design (Campbell and Stanlev, 1963:34). Rancangan penelitian disajikan pada gambar berikut:

Tabel 1. Desain Penelitian

Pretest-posttest Control Group Design

\begin{tabular}{|l|c|c|c|c|}
\hline Grup & $\begin{array}{c}\text { Randomizat } \\
\text { ion }\end{array}$ & $\begin{array}{c}\text { Period One } \\
\text { (Pre) }\end{array}$ & $\begin{array}{c}\text { Treatme } \\
\text { nt }\end{array}$ & $\begin{array}{c}\text { Period } \\
\text { Two } \\
\text { (Post) }\end{array}$ \\
\hline $\begin{array}{l}\text { Eksperim } \\
\text { en }\end{array}$ & $\mathrm{R}$ & $0_{1}$ & $\mathrm{X}$ & $\mathrm{O}_{2}$ \\
\hline Kontrol & $\mathrm{R}$ & $\mathrm{O}_{1}$ & - & $\mathrm{O}_{2}$ \\
\hline
\end{tabular}

Keterangan:

$\mathrm{O}_{1} \quad$ : Pre test pada media berbasis ICT menggunakan lectora inspire

$\mathrm{O}_{2} \quad$ : Pre test pada media konvensional

$\mathrm{X} \quad$ : Perlakuan (treatment)

$\mathrm{O}_{2} \quad$ : Post test pada multimedia berbantuan komputer

$\mathrm{O}_{2} \quad$ : Post test pada media konvensional

(http://www.hsrmethods.org/Glossary/Terms/P/Pretest\%20 Posttest\%20Control\%20Group\%20Design.aspx).

Sebelum treatment, diberikan pretest atau test awal berupa soal-soal dari materi IPS untuk melihat tingkat kondisi subyek yang berkenaan dengan variable terikat. Setelah percobaan selesai, dilakukan posttest atau tes akhir dengan soal-soal yang sama. Hasil belajar siswa pada materi IPS pada masing-masing kelompok tersebut kemudian dibandingkan untuk mengetahui pengaruh dari strategi pembelajaran yang sudah ditetapkan. Hal sama juga dilakukan dengan angket siswa mengenai minat dan sikap siswa. 
Tahap-tahap penelitian adalah sebagai berikut: (1) pembuatan instrumen dan uji coba instrumen; (2) melakukan prasurvei dan mengajukan perizinan ke sekolah-sekolah; (3) mengadakan pertemuan koordinasi dengan guru dilanjutkan dengan pembekalan mengenai media berbantuan komputer bagi guru pelaksana; (4) mengembangkan pendekatan pembelajaran bersama-sama dengan guru pada kelompok eksperimen; (5) melaksanakan posttest setelah eksperimen selesai; (6) analisis data.

Penentuan kelompok mana yang merupakan kelompok eksperimen dan kelompok mana yang merupakan kelompok kontrol dilakukan dengan cara undian. Hal ini perlu dilakukan untuk menghindari rasa subyektivitas pada peneliti. Kelompok pembelajaran berbasis ICT dengan aplikasi lectora inspire akan menerapkan pembelajaran yang didominasi dengan penggunaan komputer beserta software nya sedangkan kelompok pembelajaran non-komputer akan melaksanakan pembelajaran yang lebih didominasi dengan metode ceramah dan media cetak.

Data kemampuan afektif siswa dianalisis secara kualitatif dengan penskoran menggunakan skala likert, (Ridwan, 2003: 13) yaitu untuk pernyataan positif $5=$ sangat baik, $4=$ baik, 3 cukup, $2=$ kurang, dan 1=sangat kurang baik, sedangkan untuk pernyataan negative adalah kebalikannya.

Adapun data hasil tes untuk mengukur kemampuan kognitif siswa untuk mengetahui ada tidaknya perbedaan antara hasil posttest pada tiap kelompok dianalisis melalui tiga tahapan, yaitu tahap deskripsi data, tahap uji persyaratan analisis, dan tahap pengujian hipotesis. 


\section{Hasil Penelitian}

Pengumpulan data kemampuan kognitif yang dilihat dari hasil belajar siswa dilakukan dua kali tes yaitu tes awal sebelum dilakukan perlakuan (pre test) atau sebelum proses pembelajaran dan tes akhir sesudah dilakukan perlakuan (post test) atau sesudah proses pembelajaran berakhir menggunakan test hasil belajar. Dari beberapa data yang diperoleh dilapangan dan perhitungannya dilakukan dengan bantuan SPSS 16.0 for Window, menunjukkan perbedaan peningkatan hasil belajar pada siswa. Untuk lebih jelasnya dapat dilihat pada tabel 1 .

Tabel1

Perbandingan Hasil Pretest, Posttest dan selisih Nilai Pretest dan Postest (Gain Score) Kelas Eksperimen dan Kelas Kontrol

\begin{tabular}{|ll|r|r|r|}
\hline & Kelompok & $\mathrm{N}$ & \multicolumn{1}{c|}{ Mean } & \multicolumn{1}{c|}{$\begin{array}{c}\text { Std. } \\
\text { Deviation }\end{array}$} \\
\hline $\begin{array}{l}\text { Pre Test } \\
\text { Kognitif }\end{array}$ & $\begin{array}{l}\text { Kelompok } \\
\text { Eksperimen } \\
\text { Kelompok } \\
\text { Kontrol }\end{array}$ & 30 & 17.0000 & 1.96521 \\
\hline $\begin{array}{l}\text { Post Test } \\
\text { Kognitif }\end{array}$ & $\begin{array}{l}\text { Kelompok } \\
\text { Eksperimen }\end{array}$ & 30 & 26.2000 & 1.66919 \\
Kelompok & 30 & 21.1667 & 2.47864 \\
\hline $\begin{array}{l}\text { Kontrol } \\
\text { Koningkatan }\end{array}$ & $\begin{array}{l}\text { Kelompok } \\
\text { Eksperimen } \\
\text { Kelompok }\end{array}$ & 30 & 9.2000 & 2.86958 \\
Kontrol & 30 & 4.8667 & 2.87358 \\
\hline
\end{tabular}

Berdasar deskripsi data di atas mengenai perbandingan hasil belajar siswa dapat dilihat bahwa antara kelompok eksperimen dan kelompok kontrol terdapat perbedaan hasil belajar yang signifikan. Keduannya memiliki hasil belajar yang berbeda, baik dari segi pretest maupun postest, terutama pada peningkatan hasil belajar yang dilihat dari selisih antara nilai postes dan pretest (gain 
score) terdapat perbedaan peningkatan hasil belajar yang signifikan.

\section{Data Hasil Kemampuan Afektif}

Dalam penelitian kemampuan afektif dilihat dari aspek minat siswa terhadap materi dan proses pembelajaran. Data mengenai minat siswa terhadap materi dan proses pembelajaran IPS diperoleh melalui instrument angket yang diberikan kepada siswa pada awal pembelajaran sebelum. Dari data yan diperole dilapanan dibuat tabel rangkuman deskripsi data berdasar kemampuan afektif pada nilai pretes, postest dan selisih antara pretest dan postes atau gain score yang menunjukkan perbedaan peningkatan minat belajar pada siswa. Untuk lebih jelasnya dapat dilihat pada tabel 2 berikut:

Tabel 2

Perbandingan Hasil Pretest, Posttest dan selisih Nilai Pre Test dan Post Test (Gain Score) Kelas Eksperimen dan Kelas Kontrol dari Minat Belajar

\begin{tabular}{|ll|c|c|}
\hline & Kelompok & N & Mean \\
\hline $\begin{array}{l}\text { Pre Tes } \\
\text { Afektif }\end{array}$ & $\begin{array}{l}\text { Kelompok } \\
\text { Eksperimen } \\
\text { Kelompok } \\
\text { Kontrol }\end{array}$ & 30 & 68.1667 \\
\hline $\begin{array}{l}\text { Post Tes } \\
\text { Afektif }\end{array}$ & $\begin{array}{l}\text { Kelompok } \\
\text { Eksperimen } \\
\text { Kelompok } \\
\text { Kontrol }\end{array}$ & 30 & 30 \\
\hline $\begin{array}{l}\text { Peningkatan } \\
\text { Afektif }\end{array}$ & $\begin{array}{l}\text { Kelompok } \\
\text { Eksperimen } \\
\text { Kelompok } \\
\text { Kontrol }\end{array}$ & 30 & 83.1000 \\
\hline
\end{tabular}

Dari deskripsi data mengenai minat belajar dapat dilihat bahwa antara kelompok eksperimen dan kelompok kontrol memilki perbedaan minat belajar yang signifikan. Peningkatan 
minat siswa pada kelas eksperimen lebih tinggi dibandingkan dengan kelas kontrol.

\section{Pembahasan}

Dari hasil pengujian menggunakan uji hipotesis dan dengan menggunakan effect size memberikan hasil kesimpulan yang sama yaitu bahwa ada perbedaan peningkatan hasil belajar siswa antara kelas eksperimen dan kelas kontrol baik dari hasil belajar maupun minat belajar. Dengan memanfaatan media berbasis ICT dengan software lectora inspire siswa yang mengalami pembelajaran dengan media komputer memiliki hasil belajar yang lebih unggul dibandingkan dengan siswa yang mengalami pembelajaran dengan memanfaatkan sarana yang seadanya di kelas. Sedangkan nilai gain score dari hasil perhitungan pada kelas eksperimen dan kelas kontrol didapatkan persetase nilai pada tabel sebagai berikut.

Tabel 1

Persentase Gain Score

\begin{tabular}{|c|l|r|r|}
\hline \multirow{5}{*}{ Kelompok } & \multicolumn{1}{|c|}{ Tes } & \multicolumn{1}{c|}{$\begin{array}{c}\text { Skor } \\
\text { kemampuan } \\
\text { Kognitif }\end{array}$} & $\begin{array}{c}\text { Skor } \\
\text { Kemampuan } \\
\text { Afektif }\end{array}$ \\
\hline \multirow{5}{*}{ Eksperimen } & Rata-rata pretest & 17.00 & 68.16 \\
\cline { 2 - 4 } & $\begin{array}{l}\text { Rata-rata } \\
\text { postest }\end{array}$ & 26.20 & 83.10 \\
\cline { 2 - 4 } & Gain Score & 9.2 & 14.94 \\
\cline { 2 - 4 } & \% gain score & $54.11 \%$ & $21.91 \%$ \\
\hline \multirow{5}{*}{ Kontrol } & Rata-rata pretest & 16.30 & 66.03 \\
\cline { 2 - 4 } & $\begin{array}{l}\text { Rata-rata } \\
\text { postest }\end{array}$ & 21.16 & 74.03 \\
\cline { 2 - 4 } & Gain Score & 4.86 & 8.00 \\
\cline { 2 - 4 } & \% gain score & $29.81 \%$ & $12.11 \%$ \\
\hline
\end{tabular}

Pada perhitungan dengan menggunakan gain score

didapatkan persentase gain score hasil belajar pada kelas eksperimen sebesar 54.11\% dan untuk kelas kontrol sebesar 29.81\%, sedangkan untuk minat belajar didapatkan persentase gain score pada kelas eksperimen sebesar $21.91 \%$ dan untuk kelas 
kontrol sebesar $8.00 \%$. dari data tersebut dapat dilihat bahwa pencapaian peningkatan hasil belajar siswa dan minat belajar siswa antara kelompok eksperimen dan kelompok kontrol terdapat perbedaan hasil belajar yang signifikan. Keduannya memiliki hasil belajar yang berbeda, baik dari segi pretest maupun postest, terutama pada peningkatan hasil belajar yang dilihat dari selisih antara nilai postes dan pretest (gain score) terdapat perbedaan peningkatan hasil belajar yang signifikan.

Jika proses pembelajaran seperti ini dikaitkan dengan teori pembelajaran yang ada, kaitanya dengan penguasaan konsep siswa maka teori pembelajaran yang sesuai adalah teori Bruner. Teori Bruner mengklaim bahwa belajar adalah sebuah proses aktif dimana pembelajar membangun gagasan-gagasan baru berdasarkan pengetahuan yang telah ada sebelumnya.

Sesuai dengan teori perkembangan kognitif yang dikemukakan oleh Piaget, pembelajaran berbasis ICT dalam hal ini komputer yang menggambarkan beberapa proses yang bersifat abstrak juga bisa digunakan untuk anak usia SD. Pada usia 7 tahun keatas anak-anak berada pada periode operasional formal sehingga sudah memiliki kemampuan untuk berfikir secara abstrak. Oleh karena itu anak usia SD sudah mampu untuk menggunakan abstraksi-abstraksi dan membedakan antara yang nyata dan yang konkret dengan yang abstrak dan yang mungkin. Anak usia SD atau remaja juga mampu untuk menguji suatu hipotesis dan mampu memunculkan kemampuan nalar secara ilmiah. Anak usia SD memiliki ciri-ciri yang oleh para ahli sering digolongkan sebagai ciri-ciri individu yang kreatif, memiliki rasa ingin tahu yang besar, senang bertanya, imajinasi yang tinggi, minat yang luas, serta senang akan hal-hal yang baru. 
Media ICT juga memiliki kelebihan tersendiri, media ini memberikan pengalaman belajar melalui pengamatan langsung di lapangan atau siswa melihat sdecara langsug obyek belajar yang digunakan atau dengan kata lain ada peragaan tentang proses terjadinya suatu peristiwa atau benda sampai sampai pada penampilan tingkah laku yang dicontohkan agar dapat diketahui dan dipahami oleh peserta didik secara nyata atau tiruannya. Media ini memberikan pengalaman belajar yang melibatkan indera penglihatan dan pendengaran. Dengan adanya media komputer siswa berkesempatan mengembangkan kemampuan mengamati segala benda yang terlibat dalam proses pembelajaran serta mengambil kesimpulan-kesimpulan yang diharapkan. Dengan media ini setiap langkah pembelajaran dari hal-hal yang ditunjukkan itu dapat dilihat dengan mudah oleh siswa sehingga melalui prosdedur yang benar siswa dapat memahami materi yang diajarkan. Hal ini sejalan dengan pendapat Edgar Dale yang merancang kerucut pengalaman (Cone of Experience), yakni suatu kerucut yang menggambarkan proses memperoleh pengalaman belajar siswa yang menenpatkan pembelajaran dalam bentuk pengamatan langsung dengan benda-benda nyata atau melihat demonstrasi sebagai proses pembelajaran yang lebih memberikan hasil yang lebih positif dalam proses pembelajaran dibandingkan dengan melihat media non komputer.

Selain itu, untuk anak usia SD belum semuannya mempunyai kemampuan untuk berpikir secara abstrak. Walaupun sebagia sudah mampu berpikir logis tentang berbagai hal gagasan yang abstrak, menalar secara logis, dan menarik kesimpulan dari informasi yang tersedia, tetapi beberapa orang tidak sepenuhnya mencapai perkembangan sampai tahap ini, sehingga siswa tidak mempunyai ketrampilan berpikir seorang dewasa dan tetap 
menggunakan penalaran dari tahap operasional konkrit. Pembelajaran dengan menggunakan media pembelajaran berbasis ICT dengan software Lectora Inspire ini tentu merupakan media yang sangat tepat untuk tipe anak tersebut.

Berdasarkan pemaparan di atas dapat disimpulkan bahwa baik media komputer maupun media non komputer (media cetak) sama baiknya dalam meningkatkan hasil belajar siswa. Kedua medai ini dapat digunakan dalam pembelajaran IPS di SD karena pada usia tersebut anak-anak sudah bisa berpikir konkrit dan mulai berpikir sdecara abstrak. Hal ini sesuai dengan perkembangan kognitif, dimana pada usia 7-11 tahun anak-anak sudah bisa berpikir secara konkrit dan belajar dari benda-benda nyata yang ada disekitarnya. Pada usia 11 tahun ke atas tingkat perkembangan kognitif anak-anak sudah memasuki tingkat operasional formal sehingga sudah dapat berpikir secara abstrak.

Multimedia berbantuan komputer dan media non komputer (media cetak) juga memiliki kelebihan masing-masing, media komputer memiliki kemampuan untuk menggambarkan proses materi pelajaran IPS yang bersifat abstrak yang tidak bisa dilakukan oleh media non komputer, namun media non komputer juga memilki kelebihan yaitu dapat memberikan pengalaman belajar melalui pengamatan secara langsung dan menurut Edgar Dale dalam pengalamannya (cone of experience) menyatakan banhwa pembelajaran dalam bentuk pengamatan langsung dengan benda-benda nyata atau melihat demonstrasi sdebagai proses pembelajaran yang memberikan hasil belajar yang lebih positif dalam proses pembelajaran dibandingkan dengan media non komputer .

Berdasarkan pembahasan di atas dapat disimpulkan bahwa, baik media berbasis ICT dalam hal ini komputer dan media non 
komputer (media cetak) dapat digunakan sebagai salah satu alternatif media pembelajaran pada materi Teknologi dan Komunikasi. Hal ini didukung oleh karakteristik materi Teknologi dan Komunikasi yang bersifat abstrak sehingga dibutuhkan media yang dapat memvisualisasikan kepada siswa.

Temuan dalam penelitian menguatkan penelitian-penelitian sebelumnya. Penelitian yang dilakukan oleh Sharon Judge (2005:91) menyimpulkan bahwa akses dan penggunaan komputer di rumah, di ruang kelas, dan komputer di sekolah berkorelasi positif dengan prestasi akademik. Begitu juga dengan penelitian yang dilakukan oleh Abdullah (2010:90) menyimpulkan bahwa pembelajaran berbantuan komputer berpengaruh positif terhadap prestasi belajar siswa. Demikian juga kesimpulan penelitian yang dilkaukan oleh Estina Ekawati (2009: ii) bahwa pembelajaran berbantuan ICT lebih unggul dalam meningkatkan kemampuan afektif dan kognitif siswa dibandingkan dengan pembelajaran konvensional.

\section{Simpulan}

Berdasar analisis dan pembahasan hasil penelitian dapat disimpulkan bahwa:

1) Pembelajaran IPS menggunakan media berbasis ICT dengan menggunakan aplikasi Lectora Inspire berpengaruh positif dalam meningkatkan kemampuan kognitif siswa dibandingkan pembelajaran dengan menggunakan media cetak pada pokok bahasan Teknologi Komunikasi pada kelas IV semester SD Negeri Gedongtengen Yogyakarta tahun ajaran 2012/2013 (t= 9.226 dan $\mathrm{p}=0.004)$

2) Pembelajaran IPS menggunakan media berbasis ICT dengan menggunakan aplikasi Lectora Inspire berpengaruh positif dalam meningkatkan kemampuan Afektif siswa dibandingkan 
pembelajaran dengan menggunakan media cetak pada pokok bahasan Teknologi Komunikasi pada kelas IV semester SD Negeri Gedongtengen Yogyakarta tahun ajaran 2012/2013 ( $\mathrm{t}=$ 7.098 dan $\mathrm{p}=0.001)$.

\section{Saran}

1. Pemanfaatan media ICT pada mata pelajaran IPS kelas IV SD dalam penelitan ini sudah teruji secara signifikan lebih unggul dalam meningkatkan kemampuan kognitif maupun afektif siswa dan adanya fasilitas yang mendukung dari sekolah yaitu tersediannya Laboratorium komputer dengan jumlah komputer yang memadai di SD Negeri Gedongtengen memungkinkan pembelajaran menggunakan media berbasis ICT Sehingga disarankan kepada guru mata pelajaran memanfaatkan media ICT dengan aplikasi lectora inspire agar peserta didik lebih berminat dalam belajar dan hasl belajar yang maksmal.

2. Diharapkan adanya inovasi secara berkelanjutan agar mutu dari media pembelajaran semacam VCD pembelajaran mempunyai kualitas yang lebih baik sehingga pencapaian hasil belajar siswa lebih maksimal.

3. Guru hendaknya berusaha meningkatkan kemampuan, terutama yang berhubungan dengan penggunaan media pembelajaran sehingga ketika melakukan proses pembelajaran menggunakan media bisa lebih memotivasi siswa.

4. Penelitian mendatang agar dilakukan dengan menggunakan media yang lain yang dapat dibandingkan agar diperoleh media yang betul-betul efektif dan dapat direkomendasikan dalam rangka meningkatkan hasil belajar IPS, sehingga mampu mendongkrak rendahnya nilai IPS di kota Yogyakarta. 


\section{Daftar Pustaka}

Arikunto, Suharsimi (2006). Dasar-dasar evaluasi pendidikan. Jakarta: Bumi Aksara

Aristo Rahadi (2009). Pengertian, manfaat, dan fungsi media pembelajaran. Diambil pada tanggal 20 Januari 2010 dari http://aristorahadi.wordpress.com/2008/04/28/mediapembelajaran-dalam- pendidikan-jarak-jauh/.

Arsyad, Azhar. (2009). Media 1158 xjaran. Jakarta. Rajawali pers

Campbell, D. dan J. Stanley. 1963. Experimental and QuasiExperimental Designs for Research, Boston, MA: Houghton Mifflin Company. 1963. Experimental dan QuasiEksperimental Desain Penelitian, Boston, MA: Houghton Mifflin Company. Diambil pada tanggal 4 November 2010 dari http://www.hsrmethods.org/Glossary/Terms/P/Pretest\%20P osttest $\% 20$ Control\%20Group\%20Design.aspx

Creswell, John W. (2005). Educational research: : planning, conducting, and evaluating quantitative and qualitative research, $3^{\text {rd }}$ edition. New Jersey: Pearson Prentice Hall

Depdiknas. (2006). Peraturan Pemerintah Pendidikan Nasional No 22, Tahun 2006, tentang Standar Isi Pendidikan.

Estina Ekawati (2008) dengan judul "Pembelajaran Matematika Berbantuan ICT dalam Meningkatkan Kemampuan Kognitif dan Afektif Siswa. Tesis diambil dari http://pasca.uny.ac.id/?p=427

Etin Solihatin \& Raharjo. (2008). Cooperatif learning analisis model pembelajaran IPS. Jakarta: Bumi Aksara.

Fraenkel, J.R \& Wallen, N.E. (1993). How to design and evaluate research in education, $2^{\text {nd }}$ edition. New York: McGraw-Hill Inc

Gall, M.D, Gall, J.P \& Borg, W.R. (2003). Educational Research: an introduction. Boston: Pearson Education Inc.

Heinich, et al. (1996). Instructional Media and Technologies for Learning. New Jersey: Prentice-Hall Inc.

Mardapi, Djemari. (2004). Penyusunan tes hasil belajar. Yogyakarta: UNY 